\title{
Distribution and molecular weight of dissolved DNA in subtropical estuarine and oceanic environments
}

\author{
Mary F. DeFlaun, John H. Paul \& Wade H. Jeffrey \\ Department of Marine Science, University of South Florida, 1407 th Avenue South, St. Petersburg, Florida 33701, USA
}

\begin{abstract}
Dissolved DNA and a series of microbial biomass and activity parameters were measured in offshore, coastal, estuarine and coral reef environments of the southeast Gulf of Mexico. Oceanic concentrations of dissolved DNA ranged from 0.2 to $19 \mu \mathrm{g} \mathrm{I}^{-1}$ and decreased as a function of distance from shore and depth in the water column. Dissolved DNA concentrations were greater than halt the particulate DNA content in offshore environments $(\bar{x}=63 \pm 45 \%)$, but were a smaller percentage of particulate DNA in nearshore and estuarine environments $(\bar{x}=35 \pm 21 \%)$. Dissolved DNA correlated better with bacterial parameters (i.e. bacterial direct counts, particulate DNA and thymidine incorporation) than with phytoplankton parameters (chlorophyll a, primary productivity). The molecular weight (MW) of dissolved DNA (determined by agarose gel electrophoresis) ranged from 0.12 kilobase pairs $\left(\mathrm{kb} ; 7.75 \times 10^{4}\right.$ daltons $)$ to $35.2 \mathrm{~kb}\left(2.32 \times 10^{7}\right.$ daltons $)$ for estuarine samples, while an oligotrophic environment contained smaller MW DNA (range 0.24 to $14.27 \mathrm{~kb}$ ). DNA fragments in this size range are sufficient to contain gene sequences. These results are discussed in terms of the potential for transformation by dissolved DNA.
\end{abstract}

\section{INTRODUCTION}

Deoxyribonucleic acid (DNA) is a constituent of all living cells and its presence in the dissolved organic matter of aquatic environments is widespread. Pillai \& Ganguly (1972) found between 13 and $24 \mu \mathrm{g} \mathrm{1^{-1 }}$ of dissolved DNA in Bombay Harbor, India, and Minear (1972) measured 4 to $30 \mu \mathrm{g} \mathrm{l}^{-1}$ of extracellular DNA in lake water. Breter et al. (1977) reported polyanionic thymine concentrations in seawater corresponding to a dissolved DNA concentration of $0.75 \mu \mathrm{g} \mathrm{l}^{-1}$. More recently, we have reported dissolved DNA concentrations ranging from 0.2 to $44 \mu \mathrm{g} \mathrm{l}^{-1}$ for a variety of marine, estuarine, and freshwater environments (DeFlaun et al. 1986). A comprehensive study of the distribution of extracellular DNA has not been performed previously, perhaps due to the complexity or lack of sensitivity of methods to determine dissolved DNA at ambient concentrations.

Dissolved DNA may be an important component of the DOM (dissolved organic matter) for microbial growth, because of its enrichment in nitrogen and phosphorous, and also as a source of nucleic acid precursors, which are energetically expensive to synth- esize de novo (Nygaard 1983). Additionally, dissolved DNA could be genetically important, encoding for gene sequences with the potential to transform microbial populations. Transformation has been demonstrated for a variety of terrestrial bacteria and genetic exchange via transformation has been observed in soil (Graham \& Istock 1978). Mechanisms of genetic exchange amongst natural populations of aquatic bacteria are poorly understood, and transformation by extracellular DNA in the marine environment has not been investigated to our knowledge.

The purpose of the present study was to measure dissolved DNA in a variety of marine environments, and to relate its abundance to the activity and biomass of autotrophic and heterotrophic microbial populations. A second objective of this study was to measure the molecular weight of dissolved DNA, and thereby determine if complete gene sequences might exist dissolved in seawater.

\section{MATERIALS AND METHODS}

Samples were taken on 4 cruises in the southeast Gulf of Mexico: Cruises 8408, 8414, and 8518 aboard 
the RV Bellows in May 1984, August 1984, and June 1985 respectively, and Cruise 8514 aboard the RV Suncoaster, in August 1985 (Fig. 1). Sampling in Tampa Bay occurred monthly during 1985 and 1986. All samples were of surface waters $(\leq 10 \mathrm{~m})$ except where noted, and were collected with 301 Niskin bottles. Water samples taken above the coral reefs of the Dry Tortugas were collected in 81 Niskin bottles by skin or SCUBA divers. Temperature and salinity were determined with a Neil Brown Smart CTD. All samples were processed and incubations initiated within $1 \mathrm{~h}$ of collection. A subsample of the water was filtered through a $1 \mu \mathrm{m}$ Nuclepore filter to provide the $<1 \mu \mathrm{m}$ fraction. All filtrations were performed at $\leq 150 \mathrm{~mm} \mathrm{Hg}$ vacuum to minimize cell lysis. Chlorophyll a, particulate DNA, and bacterial direct counts were performed as described previously (Paul et al. 1985), except that filters with particulate DNA samples were frozen in 3 $\mathrm{ml}$ of SSC buffer $(0.154 \mathrm{M} \mathrm{NaCl}, 0.015 \mathrm{M}$ sodium citrate, $\mathrm{pH} 7.0)$ at $-20^{\circ} \mathrm{C}$ until analysis. Bacterial activity was estimated by a modification of the $\left[{ }^{3} \mathrm{H}\right]$ thymidine incorporation technique described by Fuhrman \& Azam (1982). Subsamples of 2 or $5 \mathrm{ml}$ were taken in duplicate and filtered immediately on $0.2 \mu \mathrm{m}$ Nuclepore filters followed by five $2 \mathrm{ml}$ washes of ice-cold $5 \%$ $(\mathrm{w} / \mathrm{v})$ trichloroacetic acid (Paul et al. 1985). Primary productivity was measured by the ${ }^{14} \mathrm{C}$-technique with modifications as suggested by Carpenter \& Lively
(1980). Incubations were performed in acid-cleaned, autoclaved polycarbonate flasks in a water bath set on deck under 2 layers of nitex neutral density screening (Paul et al. 1986). The < $1 \mu \mathrm{m}$ fraction was generated after incubation for both primary productivity and bacterial activity methods.

Samples for dissolved DNA (100 to $1000 \mathrm{ml})$ were filtered through a $0.2 \mu \mathrm{m}$ Nuclepore filter, the filtrate precipitated with 2 volumes of ethanol and treated according to the protocol described in DeFlaun et al. (1986). The Hoechst 33258 method employed measures native double-stranded DNA. All samples were corrected for losses in recovery by addition of an internal standard to replicates. For estuarine and nearshore environments recovery of internal standards ranged from 76 to $100 \%(\bar{x}=93.4 \pm 6.52)$ while offshore recoveries ranged from 35 to $100 \%(\bar{x}=72.3 \pm 7.8 \%)$. All samples were DNase treated to correct for fluorescence other than DNA. DNase degradable fluorescence ranged from 24 to $100 \%$ and averaged $75 \pm$ $19 \%$ for all samples. Samples used to determine the molecular weight range of dissolved DNA were treated similarly, except that the final $24 \mathrm{~h}$ of dialysis was in low salt TE buffer $\left(0.2 \mathrm{M} \mathrm{NaCl}, 20 \mathrm{mM}\right.$ Tris $\mathrm{HCl}_{1} 1.0$ mM EDTA, pH 7.3 to 7.5 ) instead of SSC. After dialysis, the extracts were concentrated and purified by passage over an Elutip-d anion exchange column (Schleicher and Schuell Inc., Keene, New Hampshire, USA) and

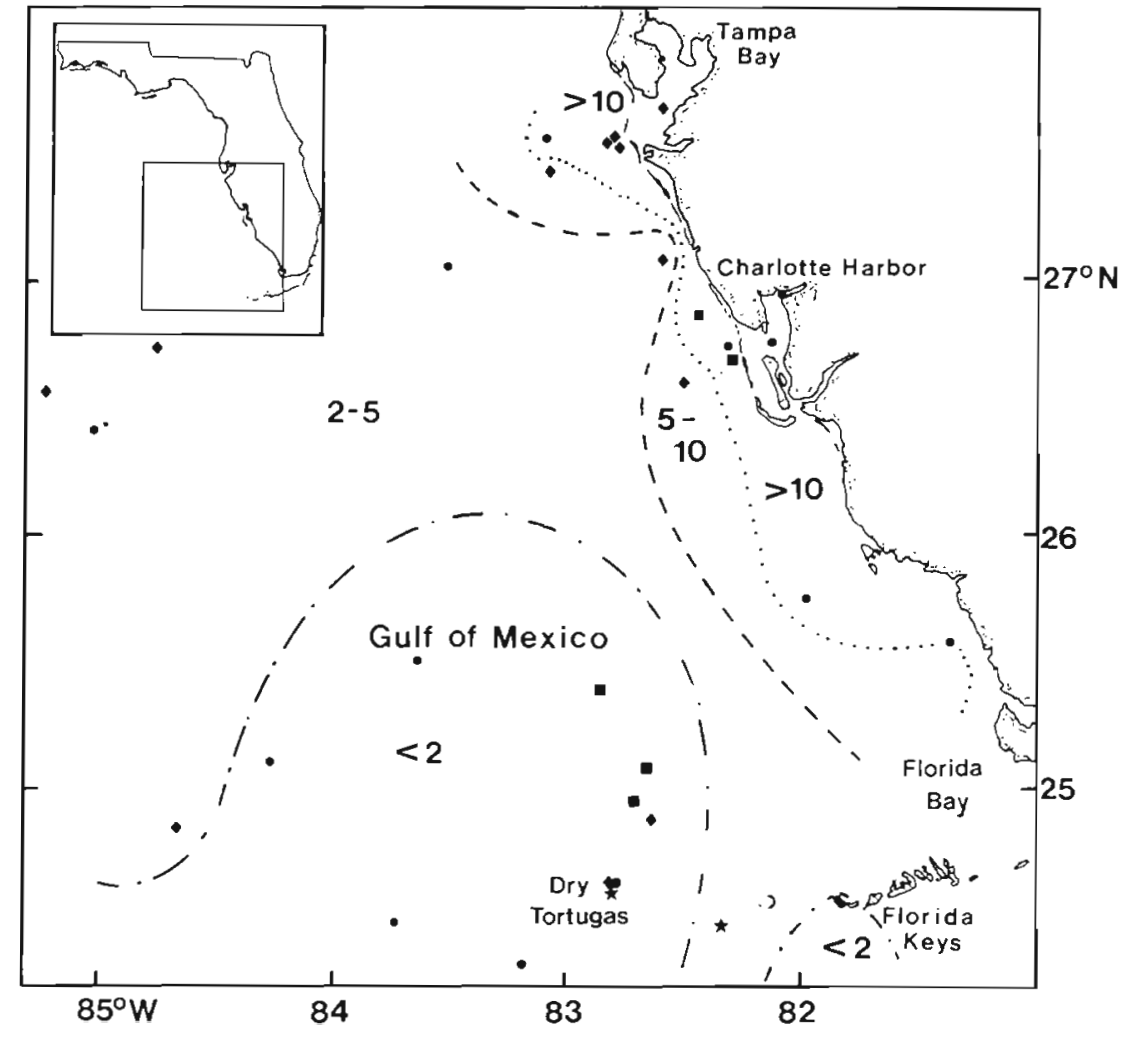

Fig. 1. Distribution of dissolved DNA in the southeastern Gulf of Mexico during summer 1984 and 1985. (•) Stations from Cruise 8408; (-) Cruise 8414; (*) Cruise 8518; (•) Cruise 8514: small asterisk indicates location of station where deep profile was taken 
eluted in $0.4 \mathrm{ml}$ of high salt TE $(1.0 \mathrm{M} \mathrm{NaCl})$. This eluate was precipitated with 2 volumes of ethanol in a $1.5 \mathrm{ml}$ microfuge tube at $-20^{\circ} \mathrm{C}$ overnight. The precipitate was collected by centrifugation for $10 \mathrm{~min}$ in an Eppendorf microcentrifuge. The pellet was resuspended in an appropriate volume of TE buffer $110 \mathrm{mM}$ Tris $\mathrm{HCl} 1.0 \mathrm{mM}$ EDTA, pH 7.6). The molecular weight range of the dissolved DNA was determined by electrophoresing the sample in a $1 \%$ agarose gel employing Hind III restricted phage $\lambda$ DNA molecular weight standards. Gels were stained and photographed according to the Hoechst 33258 technique described by DeFlaun \& Paul (1986). Several of the samples concentrated by the Elutip-d columns were subjected to RNase and DNase treatment. For DNase treatment, the $\mathrm{pH}$ of the eluate was adjusted to 5.0 by addition of 6.5 $\mu \mathrm{l}$ of $0.25 \mathrm{M}$ acetic acid. Five $\mu \mathrm{l}$ of $2 \mathrm{M} \mathrm{MgSO}_{4}$ and 100 $\mu \mathrm{l}$ of $2 \mathrm{mg} \mathrm{ml}^{-1}$ DNase I (Sigma Chemical Co.) in $0.02 \mathrm{M}$ sodium acetate buffer ( $\mathrm{pH} 5.0$; Paul \& Myers 1982) was added and the mixture was incubated in a $1.5 \mathrm{ml}$ microfuge tube for $2 \mathrm{~h}$ at room temperature. RNase treatment consisted of adding DNase-free RNase to the concentrated eluate at a final concentration of $10 \mu \mathrm{g}$ $\mathrm{ml}^{-1}$ and incubating at room temperature for $1 \mathrm{~h}$ (Maniatis et al. 1982). After incubation, the RNase- and DNase-treated samples were precipitated with 2 volumes of ethanol and prepared for electrophoresis as described above.

\section{RESULTS}

The distribution of dissolved DNA in the environments sampled appears in Fig. 1. The data for 2 consecutive summers has been plotted in this figure. Little variability exists over large areas in the offshore waters, suggesting that combining data sets from consecutive years is justified, at least for the levels of dissolved DNA found in summer. The lowest values were found in the southeastern Gulf $\left(0.2\right.$ to $\left.1.9 \mu \mathrm{g} \mathrm{l}^{-1}\right)$, an area that is strongly influenced by intrusions of oligotrophic Loop Current water onto the Florida Shelf. Higher concentrations ( 2 to $5 \mu \mathrm{g} \mathrm{l}^{-1}$ ) were found north of this area, at a latitude of approximately $27^{\circ} \mathrm{N}$. Dis- solved DNA concentrations increased shoreward with plumes of higher concentrations (10 to $19 \mu \mathrm{g} \mathrm{l}^{-1}$ ) near the mouth of Tampa Bay and Charlotte Harbor (Fig. 1). Elevated concentrations (10 to $15 \mu \mathrm{g} \mathrm{l}^{-1}$ ) were also found in Florida Bay, which is strongly influenced by the highly productive Ten Thousand Islands estuarine ecosystem.

The averages and range of values for chlorophyll $a$, particulate DNA, bacterial direct counts, thymidine incorporation, and primary production for the stations in Fig. 1 appear in Table 1. These data have been divided into 'offshore' and 'nearshore/estuarine' catagories based on the particulate DNA content: all offshore stations possessed $\leq 10 \mu \mathrm{g} \mathrm{l^{-1 }}$ DNA, while nearshore stations exceeded this. The $1 \mu \mathrm{g} \mathrm{l}^{-1}$ chlorophyll a division for offshore/nearshore environments yielded a similar separation in the data sets. Offshore waters possessed $<10^{6}$ bacteria $1^{-1},<10$ pmole thymidine incorporated into TCA precipitable material $\mathrm{l}^{-1} \mathrm{~h}^{-1}$ and $<2 \mu \mathrm{g} \mathrm{C}$ fixed $1^{-1} \mathrm{~h}^{-1}$ (Table 1). During Cruise 8514 (August 1985) the proportion of label from $\left[{ }^{3} \mathrm{H}\right]$ thymidine incorporated into protein was investigated in 10 samples. The average percent incorporated into protein was $4.3 \%$, and ranged from no detectable incorporation (5 samples) to $10 \%$, indicating a low percentage of non-specific macromolecular labelling by ${ }^{3} \mathrm{H}$ thymidine incorporation.

Fig. 2 is a plot of dissolved DNA concentrations as a function of particulate DNA values. This figure includes 47 samples from Tampa Bay taken during 1985 and 1986. A biphasic relation exists between those 2 parameters that divides the samples at the offshore/nearshore division of $10 \mu \mathrm{g}$ PDNA $^{-1}$ or $\sim 5 \mu \mathrm{g}$ dissolved DNA ${ }^{-1}$. The slope of the offshore regression $(0.75)$ is considerably steeper than the nearshore $(0.23)$, indicating that dissolved DNA is equivalent to a greater proportion of particulate DNA in the offshore environments. A t-test comparison of these data sets indicated that these slopes were indeed different $(p<0.001$ ). Division of dissolved DNA values by particulate DNA values indicated that for offshore data, dissolved DNA was $63 \pm 45 \%$ of the PDNA ( $\mathrm{n}=46$ ), whereas for nearshore data, this value was significantly lower (35 $\pm 21 \% \mathrm{n}=64, \mathrm{p}<0.001$ ).

Table 1. Averages and ranges of microbial biomass and activity parameters for sampled stations shown in Fig. 1

\begin{tabular}{|c|c|c|c|c|}
\hline \multirow[t]{2}{*}{ Parameter } & \multicolumn{2}{|c|}{ Offshore } & \multicolumn{2}{|c|}{ Nearshore and estuarine } \\
\hline & Mean $\pm S D$ & Range & Mean $\pm \mathrm{SD}$ & Range \\
\hline Particulate DNA $\left(\mu \mathrm{g} \mathrm{I}^{-1}\right)$ & $4.25 \pm 2.20$ & $0.57-8.32$ & $20.42 \pm 6.74$ & $10.6-28.7$ \\
\hline Bacterial direct counts $\left(\times 10^{9}\right.$ cells $\left.1^{-1}\right)$ & $0.470 \pm 0.264$ & $0.068-0.885$ & $1.66 \pm 0.60$ & $0.503-2.61$ \\
\hline Thymidine incorporation (pmole $\mathrm{l}^{-1} \mathrm{~h}^{-1}$ ) & $1.51 \pm 1.59$ & $0.0103-5.5$ & $48.04 \pm 30.48$ & $7.89-105$ \\
\hline Chlorophyl $a\left(\mu \mathrm{g}^{-1}\right)$ & $0.235 \pm 0.317$ & $0.0038-0.782$ & $3.57 \pm 3.24$ & $0.512-10.1$ \\
\hline Primary productivity $\left(\mu \mathrm{g} \mathrm{C} l^{-1} \mathrm{~h}^{-1}\right)$ & $0.75 \pm 0.44$ & $0.14-1.56$ & $55.85 \pm 54.01$ & $7.11-132.6$ \\
\hline
\end{tabular}




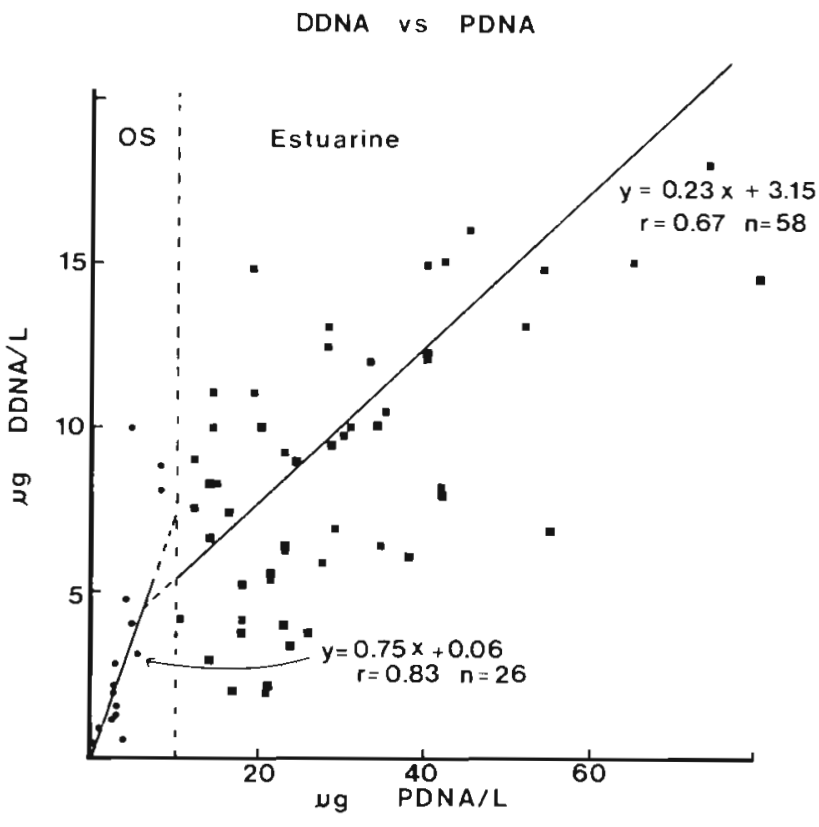

Fig. 2. Dissolved DNA (DDNA) as a function of particulate DNA (PDNA) concentration for data from stations shown in Fig. 1 and additional stations sampled during 1985 and 1986 in Tampa Bay

Dissolved DNA and the other microbial biomass and activity parameters were measured in a profile at an offshore station (indicated in Fig. 1) on Cruise 8514 (1985). The results of this profile appear in Fig. 3. Dissolved DNA values were maximal in the surface waters and decreased sharply through the thermocline. Concentrations remained relatively constant $k<0.3 \mu \mathrm{g}$ $\mathrm{l}^{-1}$ ) from 300 to $1500 \mathrm{~m}$, the greatest depth sampled. A similar dissolved DNA profile was found during Cruise 8408 the previous summer. Bacterial abundance was also greatest in the surface waters, decreasing down to $200 \mathrm{~m}$, and then constant to $1500 \mathrm{~m}$. Particulate DNA concentrations reached maximal values at $50 \mathrm{~m}$, and the profile resembled those for direct counts and dissolved DNA. The chlorophyll a profile was distinct from the others in that a strong maximum occurred at $100 \mathrm{~m}$, and values decreased sharply below this to a minimum from 200 to $1500 \mathrm{~m}$. No ${ }^{14} \mathrm{C}$ fixation could be detected at depths of $100 \mathrm{~m}$ or greater (data not shown). Similarly, thymidine incorportion was not measurable below a depth of $200 \mathrm{~m}$, and thus the data does not appear in Fig. 3.

A correlation matrix for dissolved DNA and other parameters measured on Cruise 8514 appears in Table 2 . Of the 4 cruises, the most parameters were measured on 8514 ; primary production was not measured on the other 3 , and thymidine incorporation was not measured on 8414 . Since both primary productivity and thymidine incorporation data spanned nearly 4 orders of magnitude, and would not meet assumptions of normality required for correlation analysis (Zar 1974), this data was log-transformed prior to correlation analysis. Many of the parameters showed a high degree of correlation (Table 2). Dissolved DNA correlated best with bacterial direct counts, followed by particulate DNA, and then the log of thymidine incorporation. The poorest correlation was obtained with chlorophyll $a$. Stepwise or forward multiple linear regression analysis of this data set with the Regress II statistical software by Human Systems Dynamics, Inc. (Northridge, California, USA) indicated that the only independent variable necessary to describe the dependent variable (dissolved DNA) was bacterial direct counts ( $\mathrm{r}=0.94, \mathrm{p}<$ 0.001 ). Correlation analysis of the cumulative data set for the 3 cruises 8403,8518 , and 8514 (excluding primary production measurements) indicated that dissolved DNA correlated best with particulate DNA, followed by the log of thymidine incorporation and bacterial direct counts (data not shown). Individual analysis of each of these cruises indicated that these 3 parameters yielded the highest correlation coefficients with dissolved DNA. Chlorophyll a yielded the lowest correlation coefficient with dissolved DNA for these data sets.

Table 3 displays the results of correlation analysis for the picoplankton-enriched $<1$ um ( $\mathrm{Li}$ et al. 1983) fraction of these samples for Cruise 8514. Again, dissolved DNA correlated best with bacterial direct counts.

The molecular weight range for dissolved DNA from various environments is depicted in a series of photo-

Table 2. Correlation coefficient matrix for parameters measured in whole water for Cruise 8514. DDNA: dissolved DNA; PDNA: particulate DNA; Direct counts: bacterial direct counts; Logthy: log thymidine incorporation; Chla: chlorophyll a; Log PP: log primary productivity

\begin{tabular}{lllllll}
\hline & DDNA & PDNA & Direct counts & Logthy & Chla & Log PP \\
\hline DDNA & 1.0000 & & & & \\
PDNA & 0.8133 & 1.000 & & & \\
Direct counts & 0.9421 & 0.8894 & 1.0000 & 1.0000 & 1.0000 \\
Logthy & 0.7844 & 0.9110 & 0.8270 & 0.7234 & 0.8213 \\
Chla & 0.4986 & 0.8161 & 0.5451 & 0.9180 & 1.0000 \\
Log PP & 0.7322 & 0.9204 & 0.8131 & & \\
\hline
\end{tabular}



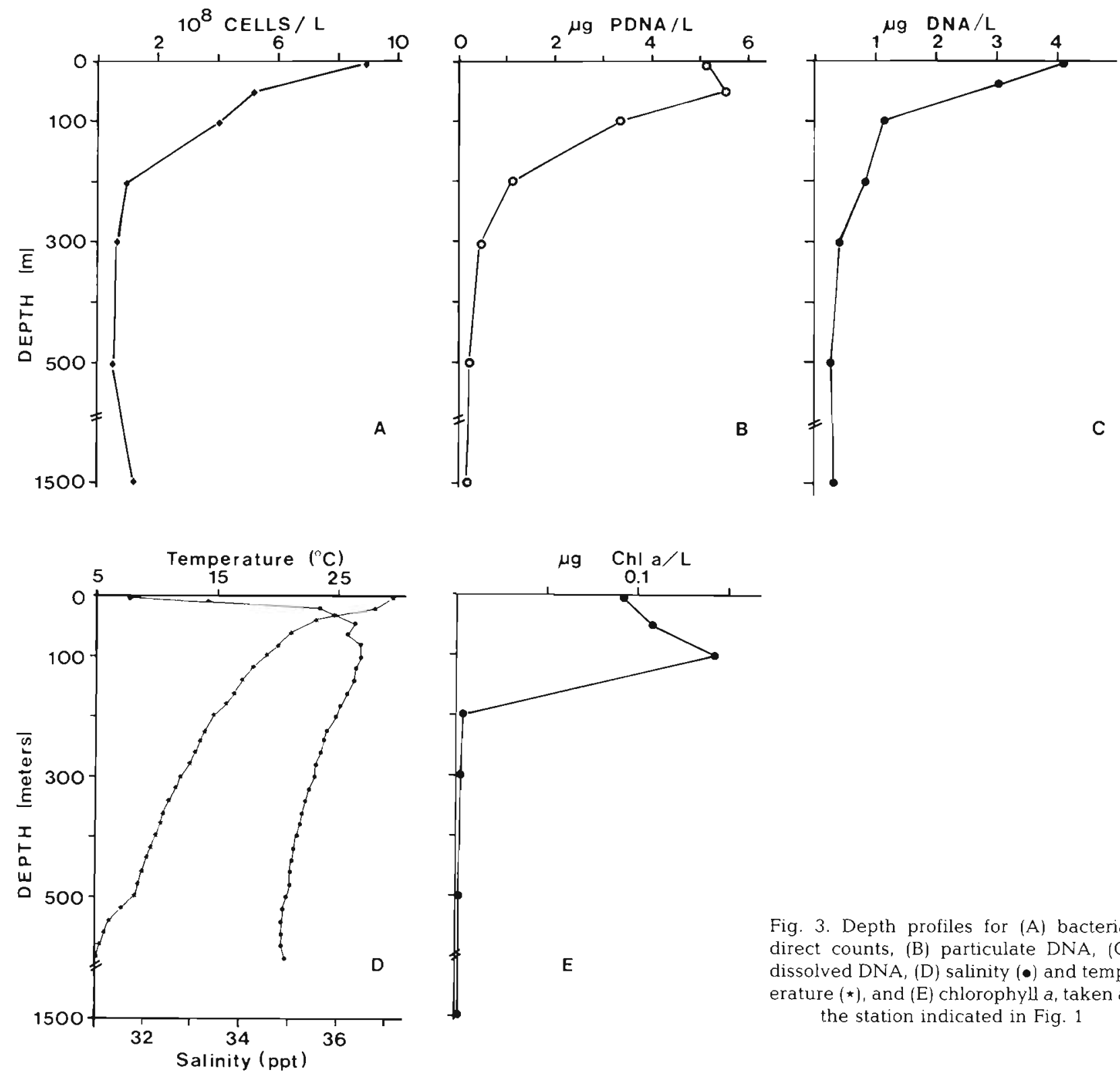

Fig. 3. Depth profiles for (A) bacterial direct counts, (B) particulate DNA, (C) dissolved DNA, (D) salinity (•) and temperature (*), and (E) chlorophyll $a$, taken at the station indicated in Fig. 1

Table 3. Correlation coefficient matrix for parameters measured in the 0.2 to $1 \mu \mathrm{m}$ fraction from water sampled on Cruise 8514 . Abbreviations as in Table 2

\begin{tabular}{|c|c|c|c|c|c|c|}
\hline & DDNA & PDNA & Direct counts & Logthy & Chla & Log PP \\
\hline DDNA & 1.0000 & & & & & \\
\hline PDNA & 0.6945 & 1.0000 & & & & \\
\hline Direct counts & 0.8390 & 0.9168 & 1.0000 & & & \\
\hline Logthy & 0.8102 & 0.8603 & 0.8214 & 1.0000 & & \\
\hline Chla & 0.7077 & 0.7861 & 0.8221 & 0.7802 & 1.0000 & \\
\hline $\log P P$ & 0.7169 & 0.9479 & 0.9001 & 0.8816 & 0.8757 & 1.0000 \\
\hline
\end{tabular}

graphs of agarose gels in Fig. 4. Fig. 4A shows untreated (Lane B), DNase (Lane C) and RNase (Lane D) digested extracts of Bayboro Harbor water (a eutrophic embayment adjoining Tampa Bay). The fluorescent material in this gel was completely digested by DNase but not by RNase. These samples contained DNA with a heterogeneous range of molecular weights. Apparent molecular weights, predicted by linear regression 


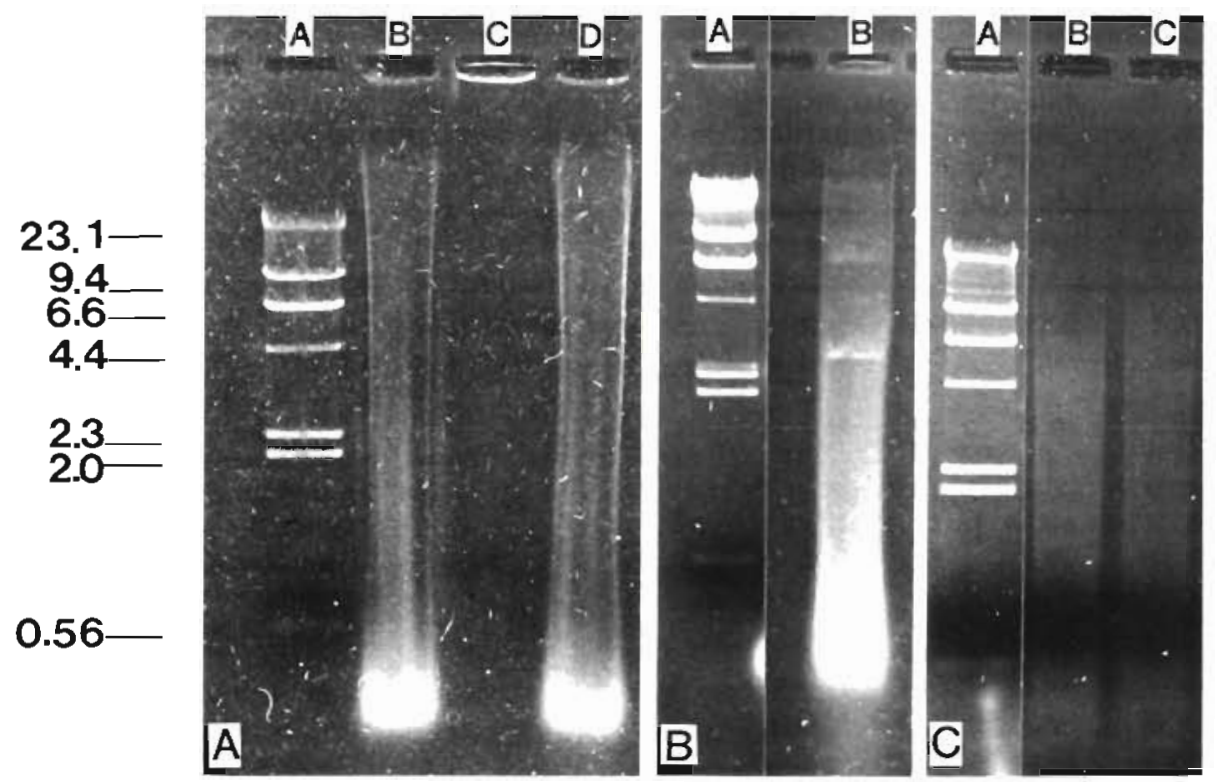

Fig. 4. Agarose gel electrophoresis of dissolved DNA concentrated extracts from 3 environments. Lane A in all cases contains Hind III phage $\lambda$ DNA standards. Molecular weights for the Hind III $\lambda$ standards are in numbers of kilobase pairs. Gel $A$, Lanes $B, C$, and $D$ contain untreated, DNasetreated and RNase-treated Bayboro Harbor DDNA concentrates, respectively. Gel B, Lane B contains Charlotte Harbor DDNA concentrate. Gel C, Lane B contains untreated and Lane $\mathrm{C}$. RNase-treated DDNA concentrate from the Dry Tortugas

analysis of the log molecular weight versus the distance migrated, ranged from 35.2 kilobase pairs (kb; $2.32 \times 10^{7}$ daltons $)$ to $0.15 \mathrm{~kb}\left(9.66 \times 10^{4}\right.$ daltons $)$.

A concentrated extract from a sampling site in Charlotte Harbor (Fig. 1) with molecular weights ranging from $25.6 \mathrm{~kb}\left(1.69 \times 10^{7}\right.$ daltons $)$ to $0.12 \mathrm{~kb}\left(7.75 \times 10^{4}\right.$ daltons) appears in Lane B of Fig. 4B. This pattern is similar to the one from Bayboro Harbor, with some very high molecular weight fragments and a preponderance of low molecular weight material; however, bands within the smear indicate concentrations of DNA at certain molecular weights. There is one band at approximately $12.5 \mathrm{~kb}\left(8.25 \times 10^{6}\right.$ daltons $)$ and another at $3.31 \mathrm{~kb}\left(2.18 \times 10^{6}\right.$ daltons $)$.

The gel in Fig. 4C contains dissolved DNA concentrated from a sample taken above a coral reef in the Dry Tortugas. Lanes B and C contain replicate samples, except that the concentrate in Lane C was RNasetreated prior to electrophoresis. The dissolved DNA in this sample appears to have a smaller range of molecular weights than the estuarine samples, extending from $14.27 \mathrm{~kb}\left(9.42 \times 10^{6}\right.$ daltons $)$ to $0.24 \mathrm{~kb}\left(1.56 \times 10^{5}\right.$ daltons) and does not have a high concentration of DNA in any one area of the smear.

\section{DISCUSSION}

The distribution of dissolved DNA found in this study follows a pattern characteristic of organic matter in seawater, with the highest concentrations in coastal waters, decreasing with distance from shore and depth in the water column (Mackinnon 1981). Nearly identical values were found during successive years at the same station or nearby stations. Thus, the distribution of concentrations depicted in Fig. 1 are probably representative of summer concentrations in this portion of the Gulf of Mexico for these 2 yr. However, we have no indication that this distribution is representative of other seasons or for previous years. The depth profile of dissolved DNA resembles the profiles for bacterial direct counts and particulate DNA, reflecting the high correlations found between these parameters (Table 2). The profile of chlorophyll a did not resemble the dissolved DNA profile, nor did dissolved DNA correlate well with chlorophyll $a$. The subsurface maximum in chlorophyll a values was found in a previous study in the Gulf of Mexico (Paul et al. 1985), as was the slight subsurface increase in particulate DNA. Subsurface maximums in chlorophyll a values may occur as a result of the density structure of the water column or as a result of behavioral and growth responses to light and nutrient levels (Cullen \& Eppley 1981)

Bacteria capable of passing $0.2 \mu \mathrm{m}$ filters ('filterable bacteria' or 'ultramicrobacteria') have been described in estuarine and marine environments (Tabor et al. 1981, Torrella \& Morita 1981, MacDonnell \& Hood $1982,1984)$. It is possible that these organisms contribute to the dissolved DNA signal. There is currently no way to estimate the abundance of these microorganisms by direct counts owing to their small size. However, we have attempted to estimate their importance by assuming that they represent a constant proportion of the $>0.2 \mu \mathrm{m}$ bacteria. If we assume ultrabacteria to represent 10 or $5 \%$ of the $>0.2 \mu \mathrm{m}$, their DNA (assuming $5.66 \mathrm{fg} \mathrm{cell}^{-1}$; Paul et al. 1985) would contribute 16.8 \pm 10.4 or $8.4 \pm 5.2 \%$, respectively, of the dissolved DNA. If their abundance was $50 \%$ of the $>0.2 \mu \mathrm{m}$ 
bacteria, their DNA would represent $84 \pm 52 \%$ of the dissolved DNA. Thus, depending on the abundance of ultramicrobacteria, they might make a significant contribution to the dissolved DNA signal. Mary Hood (pers. comm.) has estimated ultramicrobacterial abundance by an MPN (most probable number) method, and compared these numbers to the total CFUs (colonyforming units) present. Both techniques will probably underestimate bacterial abundance by 3 orders of magnitude, so that their ratio might enable estimation of \% ultramicrobacteria present. Her numbers for Perdido Bay, Florida, range from $6 \times 10^{-6}$ to $0.1 \%$, a proportion much smaller than any we have assumed above. Multiplying CFUs by 1000 yields a range of ultramicrobacterial concentrations from 10 to $6000 \mathrm{ml}^{-1}$, or dissolved DNA concentrations of $5.66 \times 10^{-11}$ to $3.4 \times 10^{-9} \mathrm{~g} \mathrm{l}^{-1}$, still orders of magnitude below our lowest values measured. Additionally, we have prepared dissolved DNA samples by filtration through both 0.2 and 0.1 um filters (DeFlaun et al. 1986) and have found no difference. If filterable bacteria were important in the dissolved DNA signal, we would expect lower values from the $0.1 \mu \mathrm{m}$ filtration. By the above calculations and our $0.1 \mu \mathrm{m}$ filtration data, we assume that filterable bacteria are not contributing significantly to the dissolved DNA signal. Virus particles may be contributing to the dissolved DNA signal. Again, there is no way to estimate virus abundance by direct methods. However, replicates of all of our samples are DNase-treated (DeFlaun et al. 1986), and we would expect DNA encapsulated in viral coats (and perhaps within whole cells) to be resistant to this treatment, and not calculated into our dissolved DNA estimations.

Presumably particulate DNA is the source of dissolved DNA, since cell-free DNA synthesis in seawater is not known to occur. We have previously shown that most of the particulate DNA in offshore environments ( 71 to $99 \%$ ) is associated with bacterioplankton (Paul \& Carlson 1984, Paul et al. 1987). We have also demonstrated the production of dissolved DNA by actively growing heterotrophic bacterioplankton (Paul et al. 1987). The correlations found between dissolved DNA and bacterial counts, particulate DNA, and thymidine incorporation agree with these previous observations, and imply bacterioplankton as a significant source of dissolved DNA in offshore environments. Grazing, cell lysis and/or active excretion (Hara \& Ueda 1981, Stewart \& Carlson 1986) are possible mechanisms for the production of extracellular DNA by bacteria.

The lack of correlation between dissolved DNA and phytoplankton parameters (chlorophyll a and primary productivity) and the inability to demonstrate dissolved DNA production in ${ }^{14} \mathrm{C}$ incubations of natural phytoplankton populations (Paul et al. 1987) implies a lesser role for phytoplankton in dissolved DNA production, at least in offshore environments. However, Minear (1972) conclusively demonstrated the production of extracellular DNA by a Chlamydomonas species in diffusion chamber studies. An alternate explanation for the lack of correlation with phytoplankton parameters is that phytoplankton show extreme patchiness with respect to space and time, responding to transient changes in light quality, quantity, and nutrients. Dissolved DNA may be similar to particulate DNA, or bacterial direct counts (Paul et al. 1985) in that it represents a steady-state pool that is relatively invariant over larger areas and time intervals, even though there may be short-term dynamics within the pool. Dissolved DNA, although relatively constant in terms of concentration, is rapidly hydrolyzed at near ambient concentrations by both extracellular and cellassociated enzymes (Paul et al. 1987). Turnover times of less than $1 \mathrm{~d}$ have been calculated for estuarine environments (Paul et al. 1987). However, turnover times may be greater in sediment (Novitsky 1986), where DNA may be protected from nuclease digestion (Aardema et al. 1983).

A wide molecular weight range $(<0.1$ to $>36 \mathrm{~kb})$ was found for dissolved DNA from various marine environments, as might be expected for a heterogeneous mixture of DNA. This represents the first molecular weight determination by agarose electrophoresis of dissolved DNA from a natural environment. Minear (1972) described high molecular weight DNA from lake water as that which was $\geq 50000$ daltons as determined by gel filtration on Sephadex G-75. We have demonstrated that dissolved DNA is sufficiently large enough to encode for gene sequences, assuming an average bacterial gene as $1.5 \mathrm{~kb}\left(9.9 \times 10^{5}\right.$ daltons; Zubay 1983). In fact, dissolved DNA contains plasmidsized pieces of DNA, since plasmids range in molecular weight from 1 to $200 \mathrm{~kb}$ (Maniatis et al. 1982). That dissolved DNA is this large is surprising in view of the ubiquitous presence of DNA-hydrolyzing bacteria and extracellular DNase activity in seawater (Maeda \& Taga 1973, 1974, 1976, 1981, Paul et al. 1987).

The presence of gene-sized pieces of DNA in seawater raises the question of transformation. Natural transformation is the process by which extracellular DNA is taken up by competent cells, integrated into the genome or an extrachromosomal element, and the genes expressed (Stewart \& Carlson 1986). Native, high molecular weight DNA is required for transformation (Notani \& Setlow 1974). Carlson et al. (1983) found $15 \mathrm{~kb}$-sized pieces of DNA to be optimal for transformation of Pseudomonas stutzeri. The average size of integrated transforming DNA for Bacillus subtilis was found to be $10 \mathrm{~kb}$ (Smith et al. 1981). Concino (1981, cited in Goodgal 1982) found no transformation with $0.3 \mathrm{~kb}$ fragments but low levels at $0.45 \mathrm{~kb}$ DNA. The 
molecular weight range of the extracellular DNA reported in this study is clearly in the range required for transformation. The process of transformation may have evolved from the utilization of DNA as a nutrient source, since many transformable bacteria can use the constituents of DNA as carbon, nitrogen, and energy sources (Stewart \& Carlson 1986). In previous studies, we have demonstrated the uptake of radioactivity from $\left[{ }^{3} \mathrm{H}\right.$ ]DNA by natural populations of bacteria (Paul et al. 1987). It is not known whether DNA or its components were taken up (after hydrolysis) by these microbial populations.

The process of natural transformation mediated by dissolved DNA may represent one mechanism for the flux of genetic information through aquatic microbial populations. Knowledge of such a process is important due to the impending use of genetically engineered organisms in the environment.

Acknowledgements. This work was supported by NSF grants OCE-841605 and BSR-8507343, Florida Institute of Oceanography Shiptime Awards and Gulf Oceanographic Charitable Trust Foundation Awards. Our thanks to Walter Bowles, Tracy Logue and the captains and crews of the RV Bellows and the RV Suncoaster for help in field sampling.

\section{LITERATURE CITED}

Aardema, B. W., Lorenz, M. G., Krumbein, W. E. (1983). Protection of sediment-adsorbed transforming DNA. against enzymatic inactivation. Appl. environ. Microbiol. 46: $417-420$

Breter, H.-J., Kurelec, B., Müller, W. E. G., Zahn, R. K. (1977). Thymine content of seawater as a measure of biosynthetic potential. Mar. Biol. 40: 1-8

Carlson, C. A., Pierson, L. S., Rosen, J. J., Ingraham, J. L. (1983). Pseudomonas stutzeri and related species undergo natural transformation. J. Bacteriol. 153: 93-99

Carpenter, E. J., Lively, J. S. (1980). Review of estimates of algal growth using ${ }^{14} \mathrm{C}$-tracer techniques. In: Falkowski, P. G. (ed.) Primary productivity in the sea. Plenum Press, New York, p. 161-178

Cullen, J. J., Eppley, R. W (1981). Chlorophyll maximum layers of the Southern California Bight and possible mechanisms of their formation and maintenance. Oceanologica Acta 4: 23-32

DeFlaun, M. F., Paul, J. H. (1986). Hoechst 33258 staining of DNA in agarose gel electrophoresis. J. Microbiol. Meth. 5: 265-270

Deflaun, M. F., Paul, J. H.., Davis, D. (1986). A simplified method for dissolved DNA determination in aquatic environments. Appl. environ. Microbiol. 52: 654-659

Fuhrman, J. A., Azam, F. (1982). Thymidine incorporation as a measure of heterotrophic bacterioplankton production in marine surface waters: evaluation and field results. Mar. Biol. 66: 109-120

Goodgal, S. H. (1982). DNA uptake in Haemophilus transformation. Ann. Rev. Genet. 16: 169-192

Graham, J. B., Istock, C. A. (1978). Genetic exchange in Bacillus subtilus in soil. Mol. gen. Genet. 166: 287-290
Hara, T., Ueda, S. (1981). A study on the mechanism of DNA excretion by $P$. aeruginosa KYO-1-Effect of mitomycin $c$ on extracellular DNA production. J. Agric. Biol. Chem. 45: $2457-2461$

Li, W. K. W., Subba Rao, D. V., Harrison, W. G., Smith, J. C., Cullen, J. J., Irwin, B., Platt, T (1983). Autotrophic picoplankton in the tropical ocean. Science 219: 292-295

MacDonell, M. T., Hood, M. A. (1982). Isolation and characterization of ultramicrobacteria from a Gulf Coast estuary. Appl. environ. Microbiol. 43: 566-571

MacDonell, M. T., Hood, M. A. (1984). Ultramicrovibrios in Gulf coast estuarine waters: isolation, characterization and incidence. In: Colwell, R. (ed.) Vibrios in the environment. John Wiley and Sons, New York, p. 551-562

Mackinnon, M. D. (1981). The measurement of organic carbon in seawater. In: Duursma, E. K., Dawson, R. (ed.) Marine organic chemistry: evolution, comparison, interactions and chemistry of organic matter in seawater. Elsevier, New York, p. $415-443$

Maeda, M., Taga, N. (1973). Deoxyribonuclease activity in seawater and sediment. Mar. Biol. 20: 58-63

Maeda, M., Taga, N. (1974). Occurrence and distribution of deoxyribonucleic acid-hydrolyzing bacteria in sea water. J. exp. mar. Biol. Ecol. 124: 157-169

Maeda, M., Taga, N. (1976). Extracellular nuclease produced by a marine bacterium. II. Purification and properties of extracellular nuclease from a marine Vibrio sp. Can. J. Microbiol. 22: 1443-1452

Maeda, M., Taga, N. (1981). Fluctuation of deoxyribonuclease activity from late spring to autumn in Tokyo Bay. Hydrobiologia 76 : 49-55

Maniatis, T., Fritsch, E. F., Sambrook, J. (1982). Molecular cloning: a laboratory manual. Cold Spring Harbor Laboratory, New York

Minear, R. A. (1972). Characterization of naturally occurring dissolved organophosphorous compounds. Environ. Sci. Technol. 6: 431-437

Notani, N. K., Setlow, J. K. (1974). Mechanism of bacterial transformation and transfection. Prog. nucleic Acid Res. mol. Biol. 14: 39-100

Novitsky, J. A. (1986). Degradation of dead microbial biomass in a marine sediment. Appl. environ. Microbiol. 52: $504-509$

Nygaard, 1. (1983). Utilization of preformed purine bases and nucleosides. In: Munch-Petersen, A. (ed.) Metabolism of nucleosides and nucleobases in microorganisms. Academic Press, London, p. 27-93

Paul, J. H., Carlson, D. J. (1984). Genetic material in the marine environment: implication for bacterial DNA. Limnol. Oceanogr. 29: 1091-1097

Paul, J. H., DeFlaun, M. F., Jeffrey, W H. (1986). Elevated levels of microbial activity in the coral surface microlayer Mar. Ecol. Prog. Ser. 33: 29-40

Paul, J. H., Jeffrey, W. H., DeFlaun, M. F. (1985). Particulate DNA in subtropical oceanic and estuarine planktonic environments. Mar. Biol. 90: 95-101

Paul, J. H., Jeffrey, W. H., DeFlaun, M. F. (1987). The dynamics of extracellular DNA in the marine environment. Appl. environ. Microbiol. 53: 170-179

Paul, J. H., Myers, B. (1982). Fluorometric determination of DNA in aquatic microorganisms by use of Hoechst 33258. Appl. environ. Microbiol. 43: 1393-1399

Pillai, T.N.V., Ganguly, A. K. (1972). Nucleic acid in the dissolved constituents of seawater. J. mar biol. Ass. India 14: $384-390$

Smith, H. O., Danner, D. B., Deich, R. A. (1981). Genetic transformation. A. Rev. Biochem. 50: 41-68 
Stewart, G. J., Carlson, C. A. (1986). The biology of natural transformation. A. Rev. Microbiol. 40: 211-235

Tabor, P. S., Ohwada, K., Colwell, R. R. (1981). Filterable marine bacteria found in the deep sea: distribution, taxonomy, and response to starvation. Microb. Ecol. 7: 67-83

Torella, F., Morita, R. Y. (1981). Microcultural study of bacterial size changes and microcolony and ultramicrocolony formation by heterotrophic bacteria in seawater. Appl. environ. Microbiol. 41:518-527

Zar, J. H. (1974). Biostatistical analysis. Prentice Hall, Englewood Cliffs

Zubay, G. (1983). Biochemistry. Addison-Wesley, Reading, Massachusetts

This article was presented by Dr S. Y. Newell; it was accepted for printing on March 16, 1987 